\title{
Henry A. Wallace and American Liberal Politics, 1945-1948
}

Jerold A. Rosen

Most HISTORIES OF POSTWorld War II American politics have presented a rather limited picture of Henry A. Wallace. Wallace, secretary of agriculture (1932-1940) and vice-president (1940-1944) under Franklin Roosevelt, secretary of commerce (1944-1946) under Harry Truman, and presidential candidate for the Progressive party (1948), has been depicted as either an idealistic pawn, manipulated by Communists and fellow travelers, or a prophetic and conscientious Cold War critic.

These two views both assume that Wallace maintained

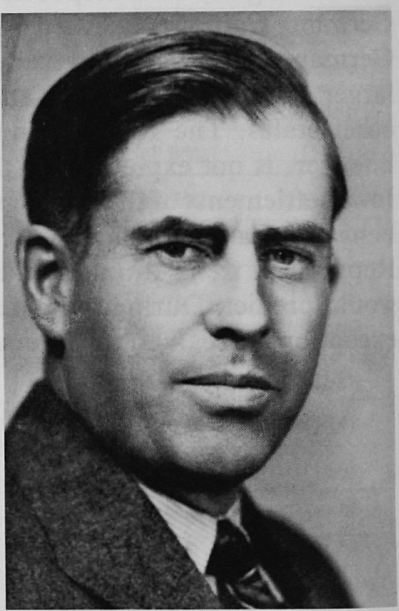

Henry A. Wallace unchanging attitudes on foreign policy from the death of Franklin Roosevelt until Wallace's Progressive party campaign for the presidency in 1948. While there were significant continuities, there were also important transitions in his ideas.

In 1945, as the United States emerged from the fiery crucible of war, Henry Wallace was one of the leading figures on the 462 
American political scene. An enthusiastic supporter of Roosevelt's foreign policy, Wallace began to grow increasingly dissatisfied with what he perceived to be a major shift in emphasis on the part of Roosevelt's successor, Harry Truman. By 1948, the time of his aborted attempt to capture the presidency, Wallace had almost completely isolated himself from the mainstream of American liberal thought. An examination of Wallace's position on American foreign policy can provide a key to understanding both the dynamics of his loss of stature as a national political figure and also the changing attitudes of United States officials on matters of Soviet-American relations.

The death of Franklin Roosevelt plunged the American liberal movement into a state of crisis. Many liberals experienced it as a tragic personal loss. Perceiving Roosevelt to be the most extraordinary political symbol of the twentieth centurythe single most prolific instigator of progressive legislation the nation had ever known - many liberals experienced feelings of aimlessness and uncertainty at his death, reflecting the extent of the mythology which had developed around him.

American liberalism, by 1945, had come to revolve around a fairly well defined set of principles. These included racial equality, the support of democratic forces overseas, and international economic security and development. Most liberals believed that an ethic of cooperation would allow industry to function according to the needs of the public welfare. Liberals envisioned a society where the abundant material benefits of industry and technology would eventually lead to a more humane system of distribution. While capitalism was seen as a necessary ingredient in this society, it was hoped that production based upon need might ultimately replace the profit motive. Thus by advocating the development of capitalism into something other than itself, liberal theoreticians inadvertently committed themselves to an ideology which was grounded in paradox. It was a system of beliefs almost certain to produce continued delusion and disappointment.

Roosevelt, the acknowledged leader of this liberal vision, had provided a sense of unity which his successor, Harry Truman, could not hope to approach. Liberals were troubled by Truman's apparent lack of the characteristics which had made 
Roosevelt such an immensely appealing figure. While Roosevelt was cosmopolitan and sophisticated, Truman had emerged from a provincial, midwestern background. His cultural heritage was not, the New Republic commented, "too well attuned to the future of a world in depression, war, and revolution." ${ }^{1}$ By comparision with Roosevelt, who had been an overwhelming mass leader and mobilizer of public opinion, Truman seemed ineffective and uninspiring. Finally, there remained the stigma of Truman's association with the infamous Pendergast machine.

LoNg BEFoRe Roosevelt's DEATH, Henry Wallace had captured the liberal imagination and was a leading symbol of the liberal spirit. When war broke out in Europe, Wallace rapidly came to interpret the conflict in terms of an "Armageddon" of liberalism. The struggle was clearly a contest between democratic freedom and fascist totalitarianism; between the forces of human reason and those of darkness. The war was not merely a contest for survival, however, but a crusade to export liberalism to every corner of the globe. Wallace was fearful of a recurrence of the economic chaos which took place after World War I. He was apprehensive that America would retreat into the isolating position often induced by a policy of economic nationalism. To avert this disaster, Wallace continually encouraged Roosevelt to concentrate on developing a systematic program of economic cooperation between the United States and competitor nations. An equitable peace settlement, Wallace hoped, would eliminate the economic rivalries which had begun the war. In the postwar world, "there must be genuine democracy in approaching the problems of the human soul and access to raw materials."

Wallace deemed the war a "second chance" for America. Now at last the world might be transformed into a society predicated on universal justice and harmony. Here, for the second time in a single generation, was an opportunity to eliminate "human suffering and poverty." ${ }^{3}$ Wallace saw World War II as the dramatic event in a 150-year-old people's revolution. After

'“'President Truman's Task," New Republic, CXII (April 23, 1945), 540.

${ }^{2}$ Norman D. Markowitz, The Rise and Fall of the People's Century: Henry A. Wallace and American Liberalism, 1941-1948 (New York, 1973), 46.

${ }^{3} \mathrm{HAW}$, "America's Second Chance," Address, April 8, 1941, reprinted in Congressional Record, 77 Congress, 1 Session, A7663-64. 
the conclusion of the war, this revolutionary process would culminate in a people's century. America had initiated the people's revolution in 1776, and now America was morally obligated to bring the fruits of her material abundance to the rest of the world.

During World War II, Wallace's statements on foreign policy echoed the liberal temper almost perfectly. The war had evolved, for Wallace and his liberal followers, into an enlargement of the political antagonisms of the Depression. Wallace's response became, in essence, merely an international extension of the New Deal. His strategy for implementing his policies required ending all political and economic imperialism, and encouraging the more advanced nations, particularly the United States, to aid development of industrial capacity in the backward countries. His program also included the subjugation of all cartels to international authority and the advancement of national self-determination everywhere. Wallace's plan, designed to provide for an expanding economy of material prosperity and abundance, would continue in effect until freedom from want had been achieved for the entire world. It called for a pursuit of war aims far removed from any attempt to reestablish the status quo. A vigorous United Nations with some degree of police power was to preside over this progressive course of action.

Wallace's theory of a united world necessitated the preservation of American-Soviet harmony. In the eyes of liberals, the Soviet Union had come to achieve a vast degree of moral legitimacy by being a partner in the wartime anti-fascist alliance. Wartime liberal rhetoric often fell into a sentimentalism which all but ignored the realities of Soviet ambitions. Liberal journals, rationalizing and excusing the most brutal Soviet activities, denounced anti-Soviet critics for sabotaging Allied unity. Most liberals regarded American-Soviet collaboration as the foundation for the world-wide New Deal and the principal deterrent to a third world war.

Henry Wallace, originally unsympathetic toward the goals of the Russian Revolution, gradually came to develop an admiration for the maturing regime. Aside from his antagonism toward Soviet atheism, Wallace's only other major criticism of Soviet conduct was based on the menace that Russia posed to American agricultural exports. 
By the 1930s, Wallace had come to regard the international situation as a confrontation between democracy and fascism. Consequently, he envisioned the Soviet Union and the United States as allies in a popular-front struggle between the civilized nations and the totalitarian powers. And by 1942, Wallace accepted the Soviet Union as an active participant in the people's revolution which had first begun in America. Thus as was the case with virtually all liberals, Wallace had come to view American-Soviet friendship as the basic element in a functional world-wide New Deal.

As the wartime alliance began to dissolve, virtually all liberals assumed that Franklin Roosevelt had developed the correct formula for dealing with the Soviet Union. Roosevelt had proved willing to concede Russian national security interests in eastern and central Europe in return for continued Allied unity, Soviet acceptance of United States interests in the Far East, and Soviet support for the United Nations. He seemed to liberals to be personally responsible for the perpetuation of Big Three unity.

Not later than the first months of 1946 the principal American diplomatic policy planners* began to assume that the Soviet Union had undertaken an expansionist tactic in eastern and central Europe which would eventually involve the United States in some type of major conflict, if not all-out war. "I'm tired of babying the Soviets," Truman declared. "Unless Russia is faced with an iron fist and strong language another war is in the making." ${ }_{4}$

The majority of liberals felt that had he lived, Roosevelt would have been able to preserve Allied unity. But Truman, the liberal press said, had abandoned Roosevelt's foreign policies. Whereas Roosevelt had possessed social grace and aristocratic bearing, Truman was blunt and undiplomatic. And, although a man of virtuous ambitions, Truman was judged by liberals as having been driven toward a split with Roosevelt's foreign policies by conservative state department advisers.

\footnotetext{
*By this date the main designers of United States diplomatic policy were Truman; James F. Byrnes, Secretary of State; W. Averell Harriman, ambassador to Moscow; James Forrestal, Secretary of the Navy; General Walter Bedell Smith; Senator Arthur H. Vandenberg of Michigan; and scholar-diplomat George F. Kennan.

${ }^{4}$ Harry S. Truman, Year of Decisions (New York, 1955), 552.
} 
Liberals who identified themselves with the legacy of the New Deal became increasingly distressed over the apparently deepening breech between the United States and the Soviet Union. Their suspicions were dramatically realized when the Truman administration initiated a "get tough" foreign policy. Washington leaders began to make public both their antagonisms toward Soviet international conduct and their desire to see America's diplomatic posture strengthened.

Perhaps the most significant event of these months was Winston Churchill's March 5, 1946 speech at Fulton, Missouri. The address, which had been given Truman's unreserved approval before it was delivered, was basically a plea that the United States deal with the Soviet Union from a vantage point of overpowering strength. This strategy of firmness constituted a dramatic shift away from the conciliatory attitude employed by Franklin Roosevelt. The stance which Truman and Byrnes adopted was contrary to Roosevelt's belief that the two nations could coexist peacefully despite their vastly different economic, social, and political systems. To ex-New Deal liberals, the Truman administration seemed all too willing to align the United States with corrupt and reactionary governments. It offered no comprehensive and constructive system for the economic redevelopment of a decimated Europe. And it was destroying the wartime anti-Fascist coalition. Many liberals, by this time, had come to assume that United States hostility was the main deterrent in Soviet-American relations.

The shift to the right in foreign affairs created a deep cleavage within the liberal movement. By the summer of 1946, two currents were beginning to emerge. One group, the cold-war liberals, supported the president's increasingly anti-Soviet posture. The second group advocated Soviet-American cooperation as a necessary prerequisite to postwar economic development and prosperity. These individuals, who shared the belief that the United States could achieve friendship with the Soviet Union without sacrificing vital national interests, gathered together under the leadership of Henry Wallace.

Appointed secretary of commerce at the beginning of 1945, Wallace had been given the post by Roosevelt as consolation for his, Wallace's, failure to be renominated to the vice-presidency 
at the 1944 Democratic convention. Concerned at first with the domestic economic situation, Wallace increasingly directed his attention toward questions of foreign policy.

The issue of postwar control of atomic energy accelerated Wallace's approaching estrangement from the Truman-Byrnes foreign policies. At a time when most prominent government officials claimed that the Soviet Union would never be scientifically capable of developing atomic weaponry, and that the United States must carefully guard its bomb formula against Soviet discovery, Wallace claimed that it was meaningless to operate on the assumption of an atomic monopoly which would prove impossible to preserve. He agreed with the atomic scientists who advocated an open exchange of scientific information with Soviet intellectuals.

Wallace believed that the control of atomic energy was the most critical issue which then confronted the United States. Incorrectly perceiving Secretary of State Byrnes to be the primary advocate of the hard-line approach toward Russia, Wallace assumed it would still be possible to persuade Truman to return to the cooperative policy of Roosevelt. But by the spring of 1946, it seemed clear that New Deal attitudes were rapidly ceasing to be a dynamic force within the Truman administration. Wallace was the final New Dealer remaining in the cabinet. He was regarded with suspicion, hostility, and viewed as a political pariah. His presence was maintained strictly for the purpose of preserving party unity.

Increasingly agitated by the deterioration of AmericanSoviet relations, Wallace began to work on an extensive position paper in the spring of 1946 . In it he expressed his concerns over the current direction of American foreign policy. He finally submitted his statements to President Truman in the form of a letter on July 23.

In his memorandum, Wallace gave an account of the historical factors which contributed to Russia's distrust and fear of the West. Throughout her history, Wallace explained, both before and after the Bolshevik Revolution, Russia was made to endure a succession of foreign invasions. In this context, the expansive United States military program must clearly appear hostile and threatening. Wallace then proceeded to advocate the 
strengthening of American-Soviet friendship through the development of strong economic ties. Trade negotiations could "well clear away the fog of political misunderstanding." The delicate problem of Russia's relationship with Eastern Europe might "more readily be solved once an atmosphere of mutual trust and confidence is established and some form of economic arrangements is worked out. . . ." As Wallace also noted, the question of Soviet postwar reconstruction and development seemed to offer "tremendous opportunities for American goods and American technicians." 5

When Truman failed to respond, Wallace made the decision to resign from the Cabinet after the November elections. He also decided to emphasize foreign policy in his campaign speeches. The first presentation came at Madison Square Garden in New York City on September 12, 1946, and it ultimately led to Wallace's dismissal from the Cabinet.

Due to the critical nature of his text, Wallace decided he would personally clear it with the president rather than send a prepared copy of the speech to the White House for routine clearance. On September 10, Wallace conferred with Truman for nearly thirty minutes. Wallace was later to state that the president read the entire text of the prepared speech. Truman listened patiently, Wallace said, while he carefully clarified and explained various passages, and elaborated upon certain significant statements. Truman later claimed that he and Wallace met for only fifteen minutes, concentrated primarily on domestic issues, and focused on the text of the approaching speech merely as an afterthought. Because of the brief duration of the meeting, Truman said, "there was, of course, no time for me to read the speech, even in part.", 6

The overall significance of the Madison Square Garden speech was that it implied only limited concessions to the Soviets. These concessions involved no sacrificing of primary national interests by the United States. Indeed, the speech contained several specifically anti-Soviet references.

What the entire episode seemed to reveal most clearly was

${ }^{5}$ Wallace's letter of July 23 was not made public until September 17. It was later reprinted under the title. "The Path to Peace with Russia," New Republic. CXV (September 30, 1946), 401-06.

${ }^{\circ}$ Russell Lord, The Wallaces of Iowa (Boston, 1947), 576; Truman, Year of Decisic..s. 557. 
the essentially monolithic structure in which American foreign policy was devised. The speech merely presented a succinct summary of Wallace's previous criticisms of United States foreign policy. Recapitulating the historical basis for Russian fears of the West, Wallace warned that a hard-line policy toward Russia would never work, because the "tougher we get, the tougher the Russians will get." The Soviets had legitimate security interests in Eastern Europe just as the United States had vital national interests in the Western Hemisphere. Wallace, therefore, proposed a sphere of influences approach to foreign policy. "We should recognize," he said, "that we have no more business in the political affairs of Eastern Europe than Russia has in the political affairs of Latin America, Western Europe and the United States." But, Wallace continued, the Soviets must not under any circumstances attempt to extend their influence beyond the boundaries of Eastern Europe, especially in the form of stirring up native communists to political action. Eastern Europe must remain accessible to American economic activity, Wallace said, because America could not allow the "door" to be closed against trade in Eastern Europe. ${ }^{7}$

At the same time that Wallace spoke in New York, Secretary of State Byrnes was in Paris at a Foreign Ministers Council meeting of the United Nations. Byrnes was attempting to negotiate European peace treaties with the Soviets, and was engaged in the delicate process of reiterating America's opposition to Soviet actions in Eastern Europe when the Garden rally took place. Wallace's blanket endorsement of a sphere of influences approach to international relations naturally caused immediate speculation and concern among foreign diplomats about the possibility of a drastic shift in the direction of American policy.

In an attempt to dispel any notions of such a shift, President Truman held a special press conference on September 14. Truman, who permitted no questions from the newsmen who were present, tried to explain that he had approved only Wallace's right to express his opinions and not the opinions themselves. Truman closed the press conference with a final succinct

'The text of Wallace's Madison Square Garden speech appeared in the New York Times. Septeniver 13, 1946. It was reprinted in Vital Speeches, XII (October 1, 1946), 738-41. 
comment: "There has been no change in the established foreign policy of our Government." 8

Truman's statements to the press did little to subdue the mounting controversy. In Paris there was still confusion as to the true nature of American policy. And as the controversy continued unabated, the American press began to turn against Wallace.

On September 17, Wallace informed presidential press secretary Charles Ross that he intended to make public the entire contents of the confidential memorandum he had sent to President Truman in July. Newspaper columnist Drew Pearson had obtained excerpts from someone in the State Department, and Wallace now attempted to prevent certain quotations from being taken out of context and used against him. A Wallace spokesman, therefore, released a prepared statement: "In view of the fact that a copy of Secretary Wallace's letter of July 23, 1946 to the President was filched from the files and is in the hands of a newspaper columnist, the Secretary of Commerce is today releasing this copy of the letter."'

Rather than easing the political tension which surrounded the controversy, this course of action was destined to have exactly the opposite effect. On September 18, Secretary of State Byrnes, still in Paris, finally broke his long silence. Byrnes immediately offered his resignation unless Truman publicly repudiated Wallace and thereby silenced the rumors about a possible shift in American policy.

On September 20, Truman, anxious to avoid further disadvantageous publicity, telephoned Wallace and asked for his resignation as secretary of commerce. "Henry," Truman said, "I am sorry, but I have reached the conclusion that it will be best that I ask for your resignation." ${ }^{10}$ Wallace calmly replied: "Why, yes, Mr. President, if that is your wish; certainly!" 11 Approximately half an hour after this exchange Truman re-

'Press Conference No. 82, Saturday, September 14, 1946, 2 p.m., page 2, Harry S. Truman Library (Independence, Missouri). Quoted in Markowitz, 'People's Century, 186.

${ }^{9}$ Press release, September 17, 1946. Quoted in Edward L. Schapsmeier and Frederick H. Schapsmeier, Prophet in Politics: Henry A. Wallace and the War Years, 1940-1965 (Ames, Iowa, 1970), 158.

${ }^{10}$ Truman, Year of Decisions, 560.

"Lord, Wallaces of Iowa, 582. 
ceived a message from Wallace. It read: "As you requested, here is my resignation. I shall continue to fight for peace. I am sure you will join me in that great endeavor." 12

Most liberals responded to the secretary of commerce's forced resignation with resentment and hostility. Quite naturally they assumed that Wallace was the only figure in American liberal politics with enough prestige and stature to provide the leadership necessary to unify the movement. By the time that Truman demanded Wallace's resignation, many liberals felt that the Truman administration had severed any claim to identity with the heritage of the New Deal. Wallace was the final and most prominent symbol of the Roosevelt administration. His dismissal seemed to point toward Truman's ultimate rejection of New Deal policies.

After his sudden departure from the Cabinet, Wallace began his attempts to unite those liberals who still sympathized with his belief in the necessity of Soviet-American cooperation. In October, Wallace announced that he had accepted the editorship of the New Republic. He then promptly set out on an international speaking tour. In his speeches and in his New Republic column, Wallace constantly challenged the principal assumptions of the American leadership. He was still hopeful, he said, that the United States and the Soviet Union might be able to reach some type of mutually equitable accord.

When President Truman announced his response to the mounting crisis in Greece in March, 1947, he finally presented to Henry Wallace a concrete issue around which Wallace could center his critical accusations. On March 12, Truman appeared before the Congress to request economic and military aid for Greece and Turkey. The president asked for $\$ 400$ million, and prepared the United States to assume British obligations in the Mediterranean.

Wallace and his supporters reacted strongly against the decision to provide aid to the reactionary Greek government, being most disturbed by the administration's failure to supply assistance through the auspices of the United Nations. In a March 13 radio address Wallace accused the administration of "betraying

${ }^{12} \mathrm{HAW}$ to Harry S. Truman, September 20, 1946. Quoted in Schapsmeier and Schapsmeier, Frophet in Politics, 160. 
the great tradition of America" and leading the American people into a "reckless adventure." The Truman Doctrine was nothing more than a sophisticated version of a "military lendlease program." The United States would soon be compelled to police "Russia's every border." ${ }^{13}$ From his editorial post at the New Republic, Wallace began a series of articles vehemently denouncing Truman's policies.

It was the emergence of the Marshall Plan in June, 1947, which finally allowed many ex-New Deal liberals to accept the Truman-Byrnes cold-war policies without completely surrendering their Rooseveltian ideals. This potentially constructive program for the redevelopment of the European economies specifically repudiated military aid and thus did not appear to be directed against any particular nation or ideology. As originally stated, the Marshall Plan was to provide economic assistance to both Western and Eastern European economies. It was also designed to include participation with the Soviet Union. In this respect the proposal clearly incorporated the principal of One World; a belief which was central to the liberal ideology which Roosevelt had embodied.

The vast majority of liberals immediately declared their support for the new program. The anti-Communist, cold-war liberals were, quite naturally, elated by the administration's ambitious initiative. Of greater consequence, perhaps, was the approval expressed by those who had originally aligned themselves with Wallace in opposition to the Truman Doctrine.

Wallace initially praised the Marshall Plan as a "great advance over the Truman Doctrine." ${ }^{14}$ But when the Soviet government declined to participate in the program, Wallace began to regard the administration's proposal with uncertainty and suspicion. He centered his criticisms around the administration's failure to dispense aid through the auspices of the United Nations.

By the beginning of 1948 , Wallace had come to believe that the humanitarian goals of the original program were being sub-

\footnotetext{
${ }^{13} \mathrm{HAW}$, Radio Address, March 13, 1947, reprinted in Congressional Record, 80 Congress, 1 Session, A1329.

${ }^{14}$ HAW, "Bevin Muddies the Waters," New Republic, CXVI (June 30, 1947), 11.
} 
ordinated to purely military objectives. The Marshall Plan, Wallace felt, had become indistinguishable from the Truman Doctrine. Both were essential elements in the Truman-Byrnes policy of containment; both were designed to aid reactionary, archaic regimes and partition Europe into two hostile power blocs.

It was not until Harry Truman's unanticipated presidential victory in 1948 that he achieved a substantial measure of acceptance with American liberals. Only then, after he had already initiated the Marshall Plan, did Truman succeed both in resolving to a large extent the liberal split on foreign policy and identifying himself with the legacy of Franklin Roosevelt.

Wallace, by 1948, had arrived at a view of United States foreign policy which proved to be the dominant theme of his campaign for the presidency. But when he failed to support the government's seemingly generous economic overture-the Marshall Plan-Wallace placed himself in a position which was increasingly more inconsistent with the ambitions of most liberals. With the exception of Rexford Tugwell, no influential New Dealer endorsed Wallace's presidential candidacy. Nor was he supported by even a single important liberal publication. By failing to acknowledge the necessity of the administration's policy of containment, Wallace had isolated himself from the mainstream of American liberal thought. In doing so, his strength as a potent, pivotal figure in American politics was almost wholly neutralized. 
Copyright of Annals of Iowa is the property of State of Iowa, by \& through the State Historical Society of Iowa and its content may not be copied or emailed to multiple sites or posted to a listserv without the copyright holder's express written permission. However, users may print, download, or email articles for individual use. 